\title{
Reflections of a "Sabra" Ethnographer: An Interview with Moshe Shokeid
}

\section{Franklin L. Hess}

Moshe Shokeid, a distinguished anthropologist who studies the cultures of both Israel and the United States, is the author of five books: The Dual Heritage: Immigrants from the Atlas Mountains in an Israeli Village (1971), The Predicament of Homecoming: Cultural and Social Life of North African Immigrants in Israel (1974), Distant Relations: Ethnicity and Politics among Arabs and North African Jews in Israel (1982), Children of Circumstances: Israeli Emigrants in New York (1988), and A Gay Synagogue in New York (1995). Recipient of the Ben-Zvi prize, which is named after Israel's popular second President, who devoted much of his political life to preserving Israel's cultural and religious diversity, Professor Shokeid has also served as the Dorot professor of Jewish Studies at New York University and has received grants from the Lucius Littauer foundation and the Memorial Foundation for Jewish Culture. While in Iowa City he is taking part in the International Forum for U.S. Studies, a project directed by Jane Desmond and Virginia Dominguez which brings Americanists from around the world to the University of Iowa to discuss and debate the United States as a cultural, historical, and political entity. He will also be spending time in New York City completing research on a community center for gay, lesbian, bisexual, and transgendered individuals. Although many of Shokeid's friends thought he was crazy for venturing to the deepest Midwest - the end of the world for them - he has found refuge in the Iowa landscape and the friendliness of Iowa City's residents.

\section{I want to begin with a biographical question. Who is Moshe Shokeid?}

I was born in Israel. My parents, however, were immigrants - my mother from Poland and my father from Lithuania. I am part of the generation that is commonly called the "sabra generation." The sabra are the first generation of Israelis born in Israel. Literally, sabra refers to a cactus which is soft and sweet inside but hard and spiny on the outside and therefore unpleasant to touch. The 
metaphor refers to the idea that that the first generation of children born in Israel was rough on the outside, but all right on the inside. We supposedly had a prickly kind of pride because we were born in the Jewish homeland, free of the long Diaspora history of oppression and submission to the surrounding society.

Professionally, I began my education with a B.A. in sociology and Middle Eastern studies and continued with a Masters degree in sociology at Hebrew University in Jerusalem. I assumed I was going to be an Middle Eastern specialist, an Orientalist, and eventually become a diplomat. The mass immigration was taking place at that time, however, and I thought that the sociological methods that were being used to examine this phenomenon were too formal and abstract. Theoretically they were fine, even grand in a Parsonian style, but we were missing the cultural and the human dimensions.

Sociology, at the time, was rooted in the notion of modernization. Because the 1950s and 1960s was the period of liberation, of independence, and of nationhood in Asia, sociologists of the time were extremely interested in studying the processes of modernization - they were assuming that most new states would inevitably choose the Western style of institutions. In Israel the sociological community followed this trend. They were studying the potential for modernization of various Israeli "ethnic" groups. (In fact, the term "ethnic" is something of a misnomer. We call them "ethnic" only because this is the closest translation in English.) While still a student, I began to notice the various groups around Israel, such as the Moroccan Jews, and I found myself wanting to look at these groups more closely, as independent cultures rather than societies inevitably moving toward modernization. This pushed me toward anthropology, which was considered the science of culture.

For my Ph.D., I attended the University of Manchester which was, at the time, an eminent school of anthropology. Professor Max Gluckman, who was chair of the department and a fairly major player in British anthropology at the time, had a research project in Israel in which he invited me to participate. I received my training under Gluckman and then went back to Israel for my fieldwork. I studied a village of Atlas Mountain Jews which was absolutely exotic to me. It wasn't as exotic as working in Asia, Africa, or Oceania, but for me it was a very important experience. There weren't many anthropologists at the time who were trained in Europe or North America but were studying in their own societies. So even though the Moroccan Jews were different to me, I still had the feeling I was engaged with them as citizens, as compatriots, as coreligionists.

Upon completing my Ph.D., I went back to Israel and got a position at the newly established Tel Aviv University. You might say that my generation was instrumental in establishing and institutionalizing anthropology in Israel. Sociology has always been Israel's dominant social science. In the late 1960s, however, anthropology's stock started to rise. At Tel Aviv University, we decided to call ourselves the Department of Sociology and Anthropology. Other universities chose similar titles. So, for nearly 30 years, anthropology has been institu- 
tionalized within the Israeli academy, but as part of sociology.

Once anthropology became an accepted part of academic life in Israel, did the anthropologists you and your cohort trained choose to work in Israel or abroad? Were there any "brave souls" who ventured to do fieldwork in places such as Papua New Guinea or Amazonia?

For many years, the majority of Israeli anthropologists were studying in Israel. Anthropology meant mostly Israeli anthropology. This was a special moment in Israel's history, as the country was attempting to absorb masses of new immigrants. As anthropologists, we defined our message in terms of our study inside Israel. This doesn't mean there weren't a few individuals who studied abroad. A few of us took part in that classical tradition of traveling overseas.

Even today, Israeli anthropologists continue to work primarily in Israel. This is, of course, also related to issues of funding. We don't have institutions and foundations like you have in America that are willing to fund research abroad. I've essentially had to support my own recent research in America through sabbaticals or by finding a temporary position at an American university, as I recently did at New York University. I've also received a few small grants from, for example, the Memorial Foundation for Jewish Culture, but these provide moral support more than anything else.

You write your ethnographies in English. If I'm not mistaken, that's not your first language.

Writing in English is simultaneously my good fortune and my predicament. For me, writing an ethnography is a double act of creation. I create ethnographies from the material I've collected and the relevant literature. Writing in English is also a creative process. I enjoy writing in Hebrew, but professionally I write mostly in English. Most of what I've published in Hebrew is actually translated from English. But writing in English is also a chore; I'm always looking for words. I always write with a thesaurus, and even then I'm never sure that what I've written is actually right. This is something I lament. I often find myself thinking that if I were able to write in my mother tongue, my life would be so much easier. So, it's both pleasure and pain. Paradoxically, I probably enjoy the experience of writing in "pain" more than the luxury of writing in my mother tongue.

You mentioned that in Hebrew there's no perfect translation for "ethnicity." Could you elaborate on the cultural differences this lack of translation suggests?

The Hebrew term is eida. In Hebrew the meaning of eida is "the congregation" or "the community." The trouble is that the best translation, which probably would be "community," is no good. We use the term in Israel to describe, for example, people who came from Yemen. The approximately 100,000 Jews who came from Yemen are termed the Yemenite eida. The 250,000 Jews who 
came from Morocco are the Moroccan eida. So eida, in this respect, cannot be compared with "ethnicity" because when we talk about "ethnic groups" there isn't the same sense of commonality - namely, that everyone's Jewish. Here in America, ethnic groups are more exclusively separate from each other. They may be either racially separate, culturally separate, or religiously separate. In Israel they may be different in terms of language, customs, folklore, and education. They may even look different, but yet we share the fact that we are all Jews. We are all equal in this way. So, even though it's not entirely accurate, Israeli anthropologists and sociologists use the term "ethnicity" for this phenomenon when they write in English and for a professional audience engaged in similar sociological issues.

Let me see if I understand the difference between "ethnicity" and " eida." In the United States the bond of commonality between people of different ethnic groups might be termed "modern." It's based on membership in that "rational," democratic political institution which we call the nation. In Israel the bond between the different eida is traditional and based on religious identity.

In a way, yes. In America you can say that the bond is based on citizenship. But when you have two groups that are as different as blacks and whites with histories so far apart, sometimes even the idea of citizenship is incapable of creating the concrete sense of a primordial bond. In Israel, the clash between the various groups is also present, but it is a clash that occurs primarily at the level of circumstances. Sooner or later, one can at least honestly believe that it will disappear. Although many newcomers from the Middle East have moved up in terms of social and economic standing, the Ashkenazim - or Jews of European extraction - have done better. This can be explained, in part, by the fact that many of them came earlier.

Notions of unity in the United States are based on a model of abstract citizenship based on the Enlightenment and Enlightenment values. Whereas in Israel...

...citizenship is a consequence of birth. In daily life, however, people use many terms that are reminiscent of other systems of classification. When immigrants from the Middle East arrived, for example, they were defined as "blacks" because they were perceived as darker - although often their skin was as light as the Ashkenazim. This was a common stereotype, but it disappeared, at least partially. In Israel, it's generally much easier to overcome an ethnic stereotype than in America.

Whereas your earlier research focused on ethnicity in Israel, your two most recent books have explored emigrant Israeli communities in the United States and a gay synagogue in New York City. How are these two phases of your academic career related? What prompted your interest in the United States?

I think the connecting thread is that I was studying social minorities - people 
who, in one way or another, have to define their positions in the society surrounding them. This was the case with the people from the Atlas mountains who came over to Israel and had to become a part of - or refuse to become a part of - Israeli society. They had to learn to present themselves as Israelis and yet preserve their culture. After finishing this study, I started an ethnography which focused on a group of Arabs living in Israel. These Arabs are the remnant of a large Arab city that disappeared after 1948 - I should say, the city didn't disappear - its residents escaped. Less than 10,000 Arabs remain from a population that once numbered over 100,000 . Now they live with Jews as next-door neighbors, as an enclave in an Israeli city. I explored the existential position of these people in terms of their forced integration into a different society. These are people who are constantly under siege, not physically, but mentally. They are Arabs surrounded by Jews. They live with Jews. They work with Jews. They may even go out for entertainment with Jewish friends or date Jews. I wanted to know how they went about maintaining their cultural identity in this situation.

When I began to study Israelis in America, I found very similar issues of identity, but a situation that was opposite to that of Arabs in Israel. These Israeli Jews are a minority in America. What do they do about it? The easy thing would be to identify with American Jewry, but they don't - at least not the first generation. So again, I had a group of people experiencing a difficult transition. They're not like American Jews who were elated to escape from Eastern Europe. These people weren't pushed out from an anti-Semitic environment or terrible economic and political conditions. On the contrary, these are people who are disparaged in Israel for leaving. They're considered traitors. There's a special term for them. They're called yordim, which means "those who go down." As I studied them, I explored how they manage to integrate in American society while at the same time preserving - or losing - their ethnic Israeli identity.

My recent work on the gay synagogue in New York is very similar. Here I also investigated people on the social and cultural edge. By having a synagogue this community makes the claim that they are Jews, but also gay - which is not a simple claim to make, because according to Jewish doctrine and the Orthodox establishment, this is an abomination. How do they manage? How do they go about being both gay and Jewish? Which is more important, being gay or being Jewish? Do they co-opt being gay into their Jewish identity, or do they do the opposite?

Your projects are all similar in that there is always a sense of doubleness or tripleness of identity in the communities you study. It seems to me, however, that there are some very real differences between an ethnography of a gay synagogue and an ethnography of a village of Atlas Mountain Jews in Israel. How would you define these differences?

First of all, I moved away from Israeli issues with the ethnography of the gay 
synagogue. One way or another, my pieces on the Moroccans, the Arabs, and the Israelis in America were all related to Israeli realities. When I was writing about Israelis in America, I was actually writing about Israeli culture. Somehow, it was much easier for me to see Israeli culture in America than it was for me, as an insider, to see my own culture in Israel. In fact, a number of reviewers actually described the book as one of the more insightful studies of Israeli culture in general.

In studying the gay synagogue, I was moving out from Israeli realities. This was a reflection of my growing alienation from what was happening there. Writing about the gay synagogue was, in a way, drawing a line between myself and my work. In all my other projects I was integrating my work with my citizenship. Now, however, I was studying as an outsider, which is what anthropologists usually do when they go to Africa, Asia, or the Trobriand Islands. As long as I studied the Moroccans, the Israeli Arabs, or the Israeli emigrants, I was reflecting on my own society and its issues. Arabs in Israel are an issue. Immigration from Israel is an issue. This gay synagogue, however, has nothing to do with Israel. I believe I have finally gone "classical" by going into a faraway, "exotic" - though not exactly exotic! - community. Now, I feel that I'm dealing with issues which are more universal.

Until now I could always be located geographically. But in terms of anthropology as a professional construction, Israel is limiting. Anthropologists who went to other places and studied a village in Tanzania or a village in India were able to become part of a vast network of experts who had common intellectual interests. Professionally, it makes their lives easier. It's always been a special effort to publish work on Israel. One has to prove it is professionally interesting even though it did not represent a larger cultural unit. Similarly, American students who wanted to study in Israel were often warned that they might get stuck - that, when they started looking for jobs, they'd be told, "You studied Israel? It's not even the Middle East." If you study an Arab village in Lebanon, Syria, or northern Africa, you become a Middle East expert. But if you study Israel, your expertise is limited to Israel.

Was it a conscious decision on your part to shift your focus away'from Israeli realities?

I was aware of what I was doing. I could see that some of my colleagues, in Israel and in America, were surprised. Up until that point I had been building a reputation, to the extent that I have a reputation, as an expert in Israeli Studies and as a specialist in issues of ethnicity. Suddenly, I seemed to move away from these areas completely, and it was not as if I'd decided to study, for example, Jamaicans or Koreans in America. I moved away from all mainstream issues of ethnicity, immigration, and related minorities to something which is entirely different and somewhat controversial - a gay synagogue.

We love to psychologize about why we do the things we do. In a way, I was recruited, regimented into dealing with national issues. At the time, I thought it 
was very important to be dealing with such issues. But I think the gay synagogue project brought me back in touch with some of the initial impulses that drew me to anthropology in the first place ... even though I found myself doing that ethnography by default. The whole project happened by coincidence. As I was studying Israelis in America and working at Queens College, a colleague of mine - I think he was later shocked that I wound up writing a monograph on the subject - asked me to try to help a student who was doing some work in this synagogue. This colleague thought that I could advise him and, since I found it very difficult to understand the synagogue from the work the student showed me, I thought the easiest thing would be to go and see it. I went and was surprised because it was completely different from what I had imagined. I had expected a small room with a few shady characters. But it was a large place and, at first glance, not much different from an ordinary synagogue. It raised my curiosity, just like the first time I entered a village of Atlas Mountain Jews.

What I thought I could contribute was an anthropological perspective. Homosexuality is a common enough topic in America. It's a political issue. It's a presidential issue. But I realized that anthropologists - those people who are supposed to be so brave, trekking off to jungles and risking their lives - are largely ignoring the topic. Of course, a lot of my peers have supported and admired this shift in my research focus, but there are also quite a few who see something flaky in my departure to this subject. In my own university I believe that, even though my position is secure and I am well known for my work, there are those who think I have lost some of my seriousness. I assume the president of my university, for instance, wouldn't be so excited to publicly acknowledge the guy who's studying the gays in New York, although he told me privately that I was "brave." For them, it would have been better if I had just continued studying ethnic and cultural issues...the "serious" stuff.

But I haven't gone back to that "serious" stuff. During my last sabbatical, I started a study of a community center for gays and lesbians in Greenwich Village. This was tangential to my earlier work on the gay synagogue. A number of the individuals who were initiated in the gay synagogue were also active in this community center. It's a very different study, however. The minute one says "synagogue," it's clear that it's an ethnic enclave. Of course, there are also a few non-Jews, but basically it's a Jewish space. The center is a much more heterogeneous institution. It caters to all sorts of gays, lesbians, bisexuals, and transgendered individuals, including whites, blacks, Asians, as well as individual of different religions. It's very kaleidoscopic institution.

I find this research very interesting, not only because it allows me to feed my curiosity, but because I find I'm being forced to do a very different kind of anthropology than what I've done previously I have to deal with a variety of groups under one roof I can't organize this study as an ordinary community study where I concentrate on one group of people and their various activities Here I have to situate myself between various groups, various activities, and different concerns. As with any project, before I started I had a different picture. I assumed there was a center, a border, a community in a building, and that 
was that. Once I started, I discovered that I couldn't study all of the community's facets because it would take the rest of my life I was involved in another type of activity almost every day. So as I was planning the structure of the book, I decided that each chapter would represent one of the groups in the center. The chapter that I'm working on right now is about the group at the center that defines itself as bisexual.

What is your perception of the ongoing Israeli-Palestinian antagonisms and territorial disputes? Are the recent peace agreements a step toward a just resolution or an nonviable half-measure? Would you comment on how Israeli-Palestinian conflict has been politicized in the United States or Israeli academy?

This is something that's very painful for me. I regret that I was a bit late in addressing this issue, but we are all just ordinary people. As long as thingš stay quiet, we let them go. In a way, I came out of the closet of academia and began talking about the Israeli-Palestinian issue in 1988. I was involved in establishing a campus protest group called "Ad-kan" which in English means "no more." We tried to raise consciousness on campus, arguing that we need to be more active and vocal about Israel-Palestine relations. This was my breakthrough in terms of Israeli politics. Since then I have adamantly and openly insisted that Israel needs to talk with the P.L.O. and work toward dividing the country into two states.

You may ask why I waited for so many years. Circumstances were quiet and difficult to figure out, and we were so busy with our work and lives. The Palestinians worked in Israel. They were part of the economy. They've been under so many other regimes. You tend to think that probably it's not that bad. But when they came out screaming, "No more"...I was shocked. At that time I was chair of the Israeli Anthropological Association, and I used my title to publish a letter in one of Israel's leading newspapers. I called it "It's Time for Civil Disobedience in Israel." For a lot of people it was a bit of a shock that this quiet professor would decide to make such noise. Academics in Israel, as in most other countries, are not involved in politics. They live in their own world and their own time.

After I wrote this letter, which was published in a very visible space in the newspaper, people started calling me and asking, "What are we going to do?" I couldn't just retreat into my home and forget about it. So we made adverstisements asking people who found the situation unbecoming to come to a meeting in one of our offices. This was the beginning of "Ad-kan," the group which sustained me during those years. One of our symbolic gestures was to produce a button which said, "No More - Speak to the P.L.O." Now, in 1988 and 1989, to come out and say that we had to speak to the P.L.O. was unbearable for many people. We were accused of being P.L.O. agents and collaborators. A group of right-wing students were calling for our ouster from the university. This was the atmosphere. We did have some allies - some old veteran leftists. But basically, we were all alone. 
I wasn't a great admirer of Mr. Rabin because I thought he should have been able to do things earlier: our attitude from the very beginning was that you can't stop history. You can't control other people. The Palestinians deserve independence, whether we like it or not. There is no other way. We're not going to throw them out. We're not going to kill them. Therefore, we need to respect their rights as much as we respect our own rights. We were also bitterly opposed to Jewish settlements in the Western Bank. We consider them to be a barrier to the peace process. I had never been to Hebron until a few weeks ago because I thought from the very beginning that this was going to be a problematic place. This whole idea of going back to the "place of the ancestors" can only result in extremism.

Thus, with the Oslo agreement, I was at last happy that the process was going forward. I assumed that once it was started, it could not be stopped. Once the Palestinians get whatever they're going to get, it will be impossible to stop them from calling themselves a state. They can call Mr. Arafat Prime Minister. They can call him King if they want, or Sultan, without Israel's intervention. In that respect, although I thought the Oslo agreement was too little and too late, I thought it was the start of something more. Of course, I don't know if it's going to lead to a peaceful co-existence. There's no guarantee that, once the territory is divided, Palestinians are going to be happy, especially since many issues are not easily resolved, like the status of Jerusalem. I have no inhibitions about a Palestinian capital in Jerusalem, but it will not be me or people like me who are going to sign these treaties.

The night Mr. Rabin was assassinated was to be one our most wonderful evenings. Supporters of the peace process had planned huge rally to celebrate the Oslo agreement and Mr. Rabin's leadership. After Mr. Rabin's death, we experienced another shock when Mr. Netanyahu was elected and not Mr. Peres. But after a while, we realized that they can't stop the peace process. You can't put the genie back in the bottle. The Palestinians have already started to experience some sort of independence, and they're going to fight any attempt to roll that back. The longer we wait, the more pain and loss of life there will be. It took Mr. Netanyahu six months to sign the Hebron agreement, but in the end he had to sign it.

\section{How are the political and scholarly sides of your life related to each other?}

I started working on the gay synagogue project after I started being more politically involved in Israel. My project with Israeli immigrants to America, however, began in the early 1980s. This fieldwork was difficult for me because the Israelis in America often expressed right-wing nationalistic attitudes. In a way, I can understand them. When you're abroad and you've apparently betrayed your country, you start thinking that you can show your loyalty by being more of a nationalist and right-winger. It colored my world. Since I was disillusioned with many things in Israel at the time - it was during the 1982 Lebanon War - it was easier for me to study the Israelis in America without contempt. Israelis 
that live abroad are often very contemptuously described in the Israeli media. My own objections to the Israeli political reality made it easier for me to look at these people in a more tolerant way.

Studying the gay synagogue was also an announcement in that it had nothing at all to do with Israel. If I had done something in Israel at that moment, it would have had to be politically active (such as studying the Palestinians or even the West Bank settlers). Anything else would have been escapism. It would have been avoiding reality - the Israeli Arab reality...Palestinian reality. But I didn't feel like I could study the Palestinians because they would see me as an Israeli. It would have been a charade. I could not study the settlers either, because of my deep resentment to their project.

So, would it be fair to say that, at that moment, the most politically committed project you could do as an anthropologist was to study in America?

In a way, it was a statement that I was doing what I thought was right. I had a difficult experience during that period of my life. I brought to the faculty senate a proposal that we would publish a declaration that we were against the closure of academic institutions on the West Bank. During the Intifada the universities were often closed because they were considered a place where Palestinian nationalism was being spread. I assumed that my colleagues, the "senators," would naturally support it. They are the full professors, the tenured faculty. We weren't asking them even to advocate a dialogue with the P.L.O. To my amazement, the proposal was voted down. I was demoralized, knowing that even on campus Israeli professors - who are not right-wingers - wouldn't come out publicly. They were too worried about what the public and government would think. They believed the university should be quiet. Of course, now everyone is supporting the peace initiative, but when it wasn't popular, they refused to stick their necks out. So I think my studying the gay synagogue was a statement that we can say what we want to do and study what we want to study. They said I was a P.L.O. agent, now they can say I'm supporting gay rights. In fact, I did not write the book as a gay rights declaration - I was looking at gay people as ordinary people.

Perhaps we could conclude with some reflections on the International Forum for U.S. Studies and your participation in it. What drew your attention to this program?

I saw the brochure at a meeting of the American Anthropological Association and I thought, "That suits me!" It's intended for overseas scholars who have been researching the United States' culture, and that is what I do. I'm now working on my third project on American soil. At the time, I wasn't particularly aware of American Studies' existence as an established academic field, but my research interests seemed germane. I remember thinking to myself how wonderful it would be to have some time to devote to research, writing, and stimulating intellectual exchange with a diverse, international body of scholars. Why 
should I be spending my entire life in the company of anthropologists and sociologists?

I assume Israel does not have an institutionalized American Studies tradition in the way that Turkey, the Netherlands, or Italy does.

Not at all.

What activities have been on the program's agenda to date and what do you hope to accomplish during your residency here at the University of Iowa?

We're just getting started, but our first meeting was a very lively discussion of the boundaries of American Studies. We also spent time identifying some of the different perspectives we bring to the study of American culture. Some of us work in institutionalized American Studies programs. Others are studying American culture and society, but from different disciplinary perspectives. These institutional factors influence the way knowledge is organized. For example, in my country, sociology and anthropology are part of the same department. In some countries, they're separate. In America, anthropology is divided into four subsections - cultural, physical, linguistic, and archaeological. At some level, it's a question of academic fashion. It is important that we have a historical perspective on the way knowledge is organized. In a way, it's a whole new set of questions about borders and identities. Anthropologists, for example, relate differently to the issues they study when communicating with different partners and audiences, be they sociologists, literary scholars, historians, or philosophers. Universities and disciplines change all the time in spite of their somewhat frozen structures. I'm planning to attend the annual meeting of the American Studies Association for the first time, and I'm looking forward to the experience. 